appear in a clearer light than they do at home, even if differing only in degree. His experience of biology in education in England should help to give a fresh interpretation to teaching practice in the Colonial Empire. Mr. Hawkins is to be succeeded by Mr. H. C. Bibby. Mr. Bibby entered Queens' College, Cambridge, in 1931 and became College Prizeman in 1933, graduating in 1935. He has examined the flora of the hot springs of Iceland, and was awarded the degree of M.Sc. of the University of Liverpool for ecological research. $\mathrm{He}$ is the author of research papers and nature study articles. He has been science master in Oulton School, Liverpool, and senior biology master in Chesterfield Grammar School. He has the advantage of considerable experience in organizing camps and in various other forms of youth work. His appointment to Mr. Hawkins's important though difficult post seems a very happy one.

\section{Presidency of the Institution of Mechanical Engineers}

Mr. Asa BInNs, the retiring president of the Institution, was born in Keighley, Yorkshire, in 1873, and was educated at the Grammar School, Keighley, and at the University of Leeds. His workshop training was obtained at the works of Messrs. Tannett Walker and Company, Leeds, and Messrs. Cole, Marchent, and Morley, Ltd., Bradford. After a period as draughtsman in Ipswich with Messrs. Ransomes, Sims, and Jefferies, he joined the staff of the Hull docks of the then North Eastern Railway in 1898, thus beginning an association with dock work which has since been continuous. A few years were spent with the Admiralty Works Department, and in $1906 \mathrm{Mr}$. Binns was appointed to the London and India Docks Company, and remained with the Company's successor, the Port of London Authority, until his retirement from the post of chief engineer in 1938, when he was retained as consultant. $\mathrm{He}$ is now consultant to Messrs. Rendel, Palmer, and Tritton, consulting engineers. He has been a member of the Institution of Mechanical Engineers since 1902. He contributed a paper on "Recent Developments in the Mechanical Equipment of the Port of London Authority" (Proc., 122, 575 ; 1932) which was presented in May 1932 at the spring meeting of the Institution in London. Mr. Binns became a Whitworth exhibitioner in 1896.

Mr. W. A. Stanier has been elected to succeed Mr. Binns as president of the Institution of Mechanical Engineers. He has been a member of Council of the Institution for many years. He served his apprenticeship with the Great Western Railway at Swindon, and reached the position of principal assistant to the Chief Mechanical Engineer of that Company. His outstanding ability as a locomotive engineer was emphasized by a striking decision of Lord Stamp in appointing him chief mechanical engineer of the London, Midland and Scottish Railway, straight from his position as principal assistant at Swindon. It is particularly fitting that the chief locomotive engineers of Great Britain should follow their famous predecessor, George Stephenson, in the president's chair.

\section{The Right Hon. Lord Harlech, G.C.M.G.}

WHen Lord Harlech takes up the office of High Commissioner in South Africa, to which his appointment was announced on February 21, he will enter upon his duties with a long experience of affairs and a judgment matured and affirmed by an intimate knowledge of the problems of British dependencies, and more especially of those of Africa, such as has been possessed by none of his predecessors in this high and important position. As the Hon. W. G. A. Ormsby-Gore, after serving as intelligence officer in the Arab Bureau and assistant political officer on the staff in the Middle East during the War of 1914-18, and holding several minor but important political appointments in the early years which followed the armistice, he became successively Under-Secretary of State for the Colonies, PostmasterGeneral, First Commissioner of Works and Secretary of State for the Colonies. In the office last named he brought to the problems of the colonial dependencies the firm conviction that scientific study and the application of the results of scientific research are essential to promote the prosperity of the Colonies themselves, and advance the interests and well-being of the inhabitants, whether European or indigenous.

Lord Harlech's acquaintance with conditions in the dependencies, gained by a personal inspection in most of them, was wider in range than that of any of his predecessors in office, and where Africa was concerned was reinforced by the detailed knowledge which had come with his experience as chairman of the East African Parliamentary Commission of 1924, and as the British representative on the Permanent Mandates Committee of the League of Nations. Lord Harlech's retirement from office after the death of his father in 1938, owing to his increased responsibilities, was felt by his colleagues and by all concerned with or interested in Colonial administration to be a great loss to the public service. His solicitude for the antiquities of England and Wales, and his services to British archæology while First Commissioner of Works, must be passed over here, but they are well known. Lord Harlech is an elected trustee of the British Museum and chairman of the governing body of the School of Oriental Studies in the University of London. He has also served as president of the Geographical Association and of Section E (Geography) of the British Association, as well as vice-president of the Museums Association.

\section{Materials for Pest Control}

Is 1937, several national industrial organizations, being impressed by the disturbing frequency of infestation of warehouses, granaries, mills and other structures of high capital value, and of ships, lighters, rolling stock, sacks and all other equipment essential to storage, process and transport, as well as by the heavy loss in value and destruction of foodstuffs, etc., set up an informal conference, under pledges of co-operation, with the object of establishing improved conditions. Infestation not being inherent in the commodities but being introduced in the links of the chain of trade, it was clearly essential to get 
general agreement on concerted action. Where standards were low or absent, proof was not lacking that there was a constant injection of infested commodities into the trade stream. At the outset it was recognized that control of the condition of the country's imports would have to commence in the countries of export, and that the aid of Government was necessary. It was also recognized as a first essential in that direction that definite indication should be given that the house here was being put in order. The most important and easiest step was that ordinary principles of cleanliness should be inculcated. This could be achieved largely by the exercise of commercial prudence. The owner of the commodity and the owner of the structure or equipment could be more mindful of their duty to each other, and the force of competition could be used to raise standards. Restraint on landing and isolation of fouled commodities again were really matters of commercial prudence, but as the most desirable precautions, if left to voluntary effort, could be offset by the recalcitrant or indifferent, something more substantial than the play of commercial prudence was needed. There remained the respective parts of the applied biologist and the chemist. Control of infestation of stocks or structures necessitated prolonged research. In this respect it was fortunate for the conference that these very matters had for a long time past been the special preoccupation of the Stored Products Laboratory of the Imperial College of Science and Technology; although it was to be regretted that that work in more recent times had suffered greatly and been circumscribed by lack of recognition.

The conference laid its problem before the Government early in 1938, and by the end of that year, decision had been taken for the establishment of a permanent research and advisory organization under the Department of Scientific and Industrial Research, industry making substantial grants towards the cost. The Department accepted the generous offer of the Imperial College to place the Stored Products Laboratory at Slough available, and the new organization inherits the benefit of the past work of the laboratory. The Department also established the Standing Conference of Co-operating and Contributing Industrial Organisations, and appointed as its chairman Mr. W. McAuley Gracie, the chairman of the former informal conference and the initiator of the industrial effort. Prof. J. W. Munro, the former director of the laboratory, has become the consultant to the Department, whilst retaining his chair in the College. This desirable conjunction of science and industry was effected prior to, and the organization was available at, the outbreak of war. In the course of the industrial investigations it has become apparent that immediate attention should be given to the establishment of a comprehensive case for guidance in production, research and application as relating to insecticides, fungicides, raticides and repellents for all purposes. Several scientific advisers to and in Government Departments have been consulted, and they fully agree as to this. Certain sectional pieces of work have been done, and available in- formation can be lifted out of dormancy, but there are gaps to be filled and a general harmony to be established, so that economic decisions may be taken and lines of research indicated. Mr. Gracie has requested Mr. W. V. Blewett, who has been released by Imperial Chemical Industries, Ltd., for this purpose, to carry out at once an economic and technical survey of the demand and production of these materials, with special reference to the potentialities and requirements of the British Empire and friendly States. Communications should be addressed to $\mathrm{Mr}$. Blewett, at 42 Hamilton House, 155 Bishopsgate, London, E.C.2.

\section{The Universities and Man-Power}

Ax the annual meeting of the Court of Governors of the University of Birmingham, the Vice-Chancellor, Dr. Raymond Priestley, paid a tribute to the attitude of the Government in recognizing the importance of the part the universities can play in the war-time economy of Great Britain. This has been directed towards the avoidance of the waste of young men of high educational attainment and intellectual promise which was so lamentably characteristic of the War of 1914-18. Dr. Priestley regards this attitude as "one of the few signs of progress we can see in a backslidden generation". But in the last few weeks, things have taken a turn for the worse. In times of crisis, when the immediate needs fill the foreground, there is a real danger that we may take a too shortsighted view. The stream of science, and applied science, graduates has so far been undammed; the trouble here is the great increase in the demand. But Dr. Priestley wonders now whether we have been wise in diminish. ing the flow of graduates in commerce, art, and law. The Government clearly has not changed its university policy, and intends to safeguard the situation as well and as promptly as it can.

"The real menace to our future is the air training scheme. No one in his senses will grudge to the R.A.F. to-day the lion's share of the flower of the nation's youth. Nevertheless, this scheme, reaching, as it does, right down into the schools, is the real danger the universities face to-day. Its success is a measure of the essential soundness, the grit, the adventurous spirit and the imagination of British youth. But this does not decrease the universities' dilemma, as they foresee the loss of their raw material for 1942 and later war years. Some of these lads, outstanding in character and intellect, who are to. day flocking to the R.A.F., should be saved from their own enthusiasm. For the sake of the nation's future, they should be directed into the universities".

\section{Government Grant to Universities}

Speaking in reply to a question by Mr. K. W. M. Pickthorn (University of Cambridge), Sir Kingsley Wood, Chancellor of the Exchequer, recalled that, in view of the vital part played by the universities in the life of the community, the importance of main. taining so far as possible the standards of university education and the essential contribution which the universities are making in a variety of ways towards 